\title{
KLASIFIKASI PASIEN KANKER PAYUDARA MENGGUNAKAN METODE ROUGH SET
}

\author{
M. Rifai1 ${ }^{1}$, S. Musdalifah², dan D. Lusiyanti ${ }^{3}$ \\ 1,2,3Program Studi Matematika Jurusan Matematika \\ Fakultas Matematika dan IImu Pengetahuan Alam Universitas Tadulako \\ Jalan Soekarno - Hatta Km. 09 Tondo, Palu 94118, Indonesia \\ 1rifaimuhamadrogo@gmail.com, ${ }^{2}$ selvymusdalifah@yahoo.com, 3Desylusiyanti@untad.ac.id
}

\begin{abstract}
Breast cancer is a condition where the cell has lost control and its normal mechanism, so that abnormal growth occurs quickly and uncontrollably that occurs in breast tissue. The basic thing that needs to be known about the cancer is the stage, so that the handling of the patient can be done correctly. In determining the cancer stage Union for International Cancer Control (UICC) uses several indicators, namely, the primary tumor which describes the size of the tumor and the expansion of the tumor to the chest wall, involvement of lymph nodes around the breast and distant metastases to other organs. Therefore, it is necessary to have a decision support system application that aims to classify cancer patient data based on the Stadium. One classification method that looks for the Decision Rule is the Rough Set. Basically this Rough set method is a decision-making method that is used to find a pattern from the data set that is processed. So that a pattern / rule can be obtained that can be used as a reference in decision making. In this study the pattern obtained as many as 16 will be entered into the Net-Bean software with java language so that it becomes a decision support system, then the system will be tested using 135 test data From these tests, namely by comparing the actual data with the results obtained from the decision support system application. So, the accuracy is $100 \%$.
\end{abstract}

Keywords : Classification, Breast Cancer Stadium, Rough Set.

\section{ABSTRAK}

Kanker payudara adalah suatu kondisi dimana sel telah kehilangan pengendalian dan mekanisme normalnya, sehingga terjadi pertumbuhan yang tidak normal dengan cepat dan tidak terkendali yang terjadi pada jaringan payudara. Hal mendasar yang perlu diketahui terhadap kanker tersebut adalah Stadiumnya, agar penanganan terhadap pasien bisa dilakukan dengan tepat. Dalam menentukan stadium kanker Union for International Cancer Control (UICC) menggunakan beberapa indikator yaitu, tumor primer yang mengambarkan ukuran tumor dan perluasan tumor hingga ke dinding dada, keterlibatan kelenjar getah bening di sekitaran payudara dan metastasis jauh ke organ tubuh yang lain. Oleh karena itu perlu adanya sebuah aplikasi sistem pendukung pengambilan keputusan yang bertujuan untuk mengklasifikasikan data pasien kanker berdasarkan Stadium. Salah satu metode klasifikasi yang mencari Aturan keputusan (Decision Rule) adalah Rough Set. Pada dasarnya metode Rough set ini adalah metode pengambilan keputusan yang digunakan untuk mencari sebuah pola dari kumpulan data yang diolah. Sehingga akan diperoleh pola/rule yang bisa dijadikan sebagai acuan dalam pengambilan keputusan. 
Dalam penelitian ini pola/rule yang di peroleh sebanyak 16 rule yang akan dimasukan kedalam softwere Net-Bean dengan bahasa java sehingga menjadi sebuah sistem pendukung pengambilan keputusan, kemudian akan dilakuakan pengujian sistem dengan menggunakan 135 data uji. Dari pengujian tersebut yaitu dengan cara membandingkan data aktual dengan hasil yang diperoleh dari Aplikasi sistem pendukung pengambilan keputusan. Maka, diperoleh akurasinya sebesar $100 \%$.

Kata kunci $\quad$ : Klasifikasi, Stadium Kanker Payudara, Rough Set.

\section{PENDAHULUAN}

\subsection{Latar belakang}

Kanker payudara adalah tumor ganas yang tumbuh di dalam jaringan payudara. Kanker bisa mulai tumbuh di dalam kelenjar susu, saluran susu, jaringan lemak maupun jaringan ikat pada payudara. Sedangkan stadium penyakit kanker adalah suatu keadaan dari hasil penilaian dokter saat mendiagnosis suatu penyakit kanker yang diderita pasiennya, sudah sejauh manakah tingkat penyebaran kanker tersebut baik ke organ atau jaringan sekitar maupun penyebaran ke tempat jauh misalnya ke paru-paru, liver, tulang, otak, dan lain-lain (Ruri $\mathrm{AH}$. dkk, 2010). Oleh karena itu, hal mendasar yang perlu diketahui adalah Stadium pada kanker tersebut yang akan menjadi pertimbangan pihak dokter dalam menentukan jenis pengobatan ataupun tindakan terhadap pasien. Banyak sekali cara untuk menentukan stadium (staging), namun yang paling banyak digunakan saat ini adalah penentuan stadium kanker yang biasa dikenal dengan istilah "TNM" yang direkomendasikan oleh UICC/AJCC (Ruri AH. dkk, 2010). Pada TNM dinilai tiga faktor utama, yaitu "T" yaitu tumor size atau ukuran tumor dan keberadaan tumor, "N" yaitu Node atau kelenjar getah bening regional, dan "M" yaitu metastasis atau penyebaran jauh.

Melihat hal ini perlu adanya suatu sistem Aplikasi pengambilan keputusan yang bisa membantu pihak dokter dalam mendiagnosa pasien penyakit kanker dengan menentukan stadiumnya berdasarkan indikator yang ada, sehingga penanganan terhadap pasien diharapkan lebih cepat.

Salah satu pendekatan yang bisa digunakan dalam mengambil keputusan adalah metode Rough Set yang bertujuan untuk mencari sebuah aturan keputusan yang akan dijadikan sebagai dasar dalam penentuan keputusan berikutnyanya.

Teori rough set adalah sebuah teknik matematik yang dikembangkan oleh Pawlack pada tahun (1980). Beberapa penelitian yang menggunakan metode Rough Set yaitu oleh M. Ardiansyah \& Zulfi Azhar (2015) dengan tujuan menganalisa Laba/Rugi pada perusahaan distributor, Nila Listiana dkk (2010) yang bertujuan untuk mendeteksi dan penanganan dini penyakit sapi, Suhardi dkk (2010) yaitu mendiagnosis penyakit Tuberkolosis. 
Berdasarkan latar belakang diatas, penelitian ini akan mengklasifikasin pasien kanker payudara berdasarkan stadium menggunakan metode rough set.

\subsection{Rumusan Masalah}

Rumusan masalah dalam penelitian ini adalah sebagai berikut :

1. Bagaimana klasifikasi pasien kanker payudara menggunakan metode Rough Set ?

2. Berapa hasil tingkat akurasi sistem pengambilan keputusan ?

\section{METODE PENELITIAN}

Penelitian ini dilakukan dengan cara menggabungkan data - data yang sama menjadi satu kelas yang disebut dengan Equivalen Class (kelas yang sama), setelah itu megolah data menggunakan metode rough set sehingga memperoleh rule - rule yang akan digunakan sebagai acuan untuk mengambil keputusan berikutnya. Dalam penelitian ini, penulis akan memasukan pola/rule ke dalam softwere Netbean dengan bahasa Java yang akan menjadi sebuah aplikasi sistem pengambilan keputusan, sehingga data - data yang akan di input akan tersimpan rapi pada sebuah database.

Teknik Rough Set merupakan sebuah teknik matematik yang dikembangkan oleh Pawlack pada tahun 1982 dan digunakan untuk analisis klasifikasi data dalam bentuk tabel. Tujuan dari analisis Rough Set adalah untuk mendapatkan perkiraan rule yang singkat dari suatu tabel. ( Beny I, 2016). Metode rough set telah berhasil diterapkan dalam berbagai tugas seperti fitur seleksi/ekstraksi, sintesis aturan dan klasifikasi, penemuan pengetahuan, dan lain-lain. Di dalam Metode Rough Set terdapat beberapa langkah - langkah penyelesaian masalah, yaitu sebagai berikut: (M. Ardiansyah \& Zulfi A, 2015).

\subsection{Sistem Informasi}

Dalam roughset, sebuah set data direpresentasikan sebagai sebuah tabel, dimana baris dalam tabel merepresentasikan objek dan kolom-kolom merepresentasikan atribut dari objekobjek tersebut.Tabel tersebut disebut dengan information system yang dapat digambarkan sebagai: $S=(U, A)$ dimana $U$ adalah set terhingga yang tidak kosong dari objek yang disebut dengan universe dan A set terhingga tidak kosong dari atribut dimana: $a: U \rightarrow V_{a}$, untuk setiap $a \in A$. Set $V_{a}$ disebut value set dari $a$, untuk tiap $a \in A$. Set $V a$ disebut value set dari $a$. $U=$ $\left\{e_{1}, e_{2}, \ldots, e_{m}\right\}$ merupakan sekumpulan example dan $A=\left\{a_{1}, a_{2}, \ldots, a_{n}\right\}$ yang merupakan atribut kondisi secara berurutan. (M. Ardiansyah \& Zulfi A, 2015)

\subsection{Sistem Keputusan}

Dalam penggunaan sistem informasi, terdapat outcome dari klasifikasi yang telah diketahui yang disebut dengan atribut keputusan. Sistem informasi tersebut disebut dengan sistem keputusan. sistem keputusan dapat digambarkan sebagai: $I S=(U,\{A, C\})$, Dimana : $U=\left\{x_{1}, x_{2}, \ldots, x_{m}\right\}$ yang merupakan sekumpulan data. $A=\left\{a_{1}, a_{2}, \ldots, a_{m}\right\}$ yang merupakan 
sekumpulan atribut kondisi secara berurutan atau atribut. $C=$ Decision attributes (atribut keputusan). (M. Ardiansyah \& Zulfi A, 2015)

\subsection{Equivalence Class}

Equivalence Class adalah mengelompokkan objek-objek yang mempunyai nilai atribut kondisi dan keputusan yang sama menjadi satu bagian. (Beny I, 2016).

\subsection{Matrix Discernibility}

Discernibility Matrix terdiri dari sekumpulan atribut yang berbeda antara object $X_{i}$ dan $X_{j}$. Pada matrix discernibility ini akan dibandingkan isi sebuah atribut antara suatu objek dengan objek lainnya. Dalam proses membandingkan ini, yang diperhatikan hanya atribut kondisinya saja, jika nilai atributnya sama maka tidak akan menghasilkan suatu nilai, tetapi akan memberi suatu nilai jika nilai atribut yang dibandingkan berbeda. (Beny I, 2016).

\subsection{Matrix Discernibility Modulo D}

Sama seperti Discernibility Matrix, pada Discernibility Matrix Modulo D juga terdiri dari sekumpulan atribut yang berbeda antara objek $X_{i}$ dan $X_{j}$. Proses untuk menghasilkan Discernibility Matrix Modulo D ini juga membandingkan isi sebuah atribut suatu objek dengan objek lainnya. Perbedaannya dengan Discernibility Matrix adalah proses membandingkannya, yang diperhatikan tidak hanya atribut kondisinya saja, tetapi juga atribut keputusannya. Jika nilai atributnya sama maka tidak menghasilkan suatu nilai, tetapi jika nilai atribut yang dibandingkan berbeda maka akan menghasilkan suatu nilai. (Beny I, 2016).

\subsection{Reduct}

Reduct adalah penyeleksian atribut minimal (interesting attribute) dari sekumpulan atribut kondisi dengan menggunakan Prime Implicant fungsi Boolean. Kumpulan dari semua Prime Implicant mendeterminasikan sets of reduct. (M. Ardiansyah \& Zulfi A, 2015).

\subsection{Aturan Keputusan}

Aturan keputusan adalah suatu metode rough set untuk menghasilkan rules berdasarkan equivalence class dan reduct. Pada aturan keputusan terdiri dari if then atau if $f$ then $g$ yang dapat direpresentasikan sebagai $f \rightarrow g$. Pada rule $f \rightarrow g$ bagian $f$ disebut sebagai condition (kondisi) dan bagian g disebut conclusion (kesimpulan). Aturan keputusan merupakan tujuan akhir dari metode Rough set, yaitu untuk mendapatkan sebuah pengetahuan atau rules dari sekumpulan data yang akan dijadikan sebagai acuan dalam mengambil keputusan berikutnya. (Nila L. dkk, 2015) 


\section{HASIL DAN PEMBAHASAN}

Pada bagian ini akan membahas tentang implementasi metode Rough set dalam mengklasifikasi stadium kanker payudara. Dalam penelitian ini, penulis akan memasukan pola/rule ke dalam softwere Netbean dengan bahasa Java yang akan menjadi sebuah aplikasi sistem pengambilan keputusan, sehingga data - data yang akan di input akan tersimpan rapi pada sebuah database.

\subsection{Proses Pengolahan Data Menggunakan Metode Rough Set}

\subsubsection{Sistem Informasi}

Dalam rough set, sebuah set data direpresentasikan sebagai sebuah tabel, dimana baris dalam tabel merepresentasikan objek dan kolom-kolom merepresentasikan atribut dari objek-objek tersebut. Pada sistem informasi, data yang ditampilkan adalah data yang di kategorikan sebgai atribut kondisi yaitu ukuran tumor, perluasan tumor, kelenjar getang bening dan penyebaran jauh. Berikut adalah tabel informasi sistem dari data pasien kanker payudara.

Tabel 1 : Sistem Informasi

\begin{tabular}{|c|c|c|c|c|}
\hline Pasien & UkuranTumor & PerluasanTumor & $\begin{array}{c}\text { Kelenjar Getah Bening } \\
(\text { KGB })\end{array}$ & Penyebaran Jauh \\
\hline 1 & SEDANG & TIDAK & N2 & M0 \\
\hline 2 & KECIL & TIDAK & N2 & M0 \\
\hline 3 & SEDANG & TIDAK & N2 & M0 \\
\hline$\ldots$ & $\ldots$ & $\ldots$ & $\ldots$ & $\ldots$ \\
\hline 135 & SEDANG & TIDAK & N1 & M0 \\
\hline
\end{tabular}

\subsubsection{Sistem Keputusan}

Dalam penggunaan sistem informasi, terdapat outcome dari klasifikasi yang telah diketahui yang disebut dengan atribut keputusan. Maka pada informasi sistem akan ditambahkan satu atribut keputusan yaitu stadium. Sistem informasi tersebut disebut dengan sistem keputusan.

Tabel 2 : Sistem keputusan

\begin{tabular}{|c|c|c|c|c|c|}
\hline Pasien & Ukuran Tumor & $\begin{array}{c}\text { Perluasan } \\
\text { Tumor }\end{array}$ & KGB & Penyebaran jauh & Stadium \\
\hline 1 & SEDANG & TIDAK & N2 & M0 & III \\
\hline 2 & KECIL & TIDAK & N2 & M0 & III \\
\hline 3 & SEDANG & TIDAK & N2 & M0 & III \\
\hline$\ldots$ & $\ldots$ & $\ldots$ & $\ldots$ & $\ldots$ & $\ldots$ \\
\hline 135 & SEDANG & TIDAK & N1 & M0 & II \\
\hline
\end{tabular}




\subsubsection{Equivalence Class}

Equivalence Class (EC) adalah mengelompokan objek-objek yang mempunyai nilai atribut sama mencadi satu kelempok. Misal pada Tabel 2 pasien 1 dan pasien 3 memiliki nilai atribut yang sama maka data pasien tersebut akan terhimpun menjadi satu kelompok yaitu EC6.

Tabel 3 : Equivalence Class

\begin{tabular}{|c|c|c|c|c|c|}
\hline EC & Ukuran Tumor & $\begin{array}{c}\text { Perluasan } \\
\text { Tumor }\end{array}$ & KGB & $\begin{array}{c}\text { Penyebaran } \\
\text { jauh }\end{array}$ & Stadium \\
\hline EC1 & KECIL & TIDAK & N0 & M0 & I \\
\hline EC2 & KECIL & TIDAK & N1 & M0 & I \\
\hline EC3 & SEDANG & TIDAK & N0 & M0 & II \\
\hline EC4 & BESAR & TIDAK & N0 & M0 & II \\
\hline EC5 & SEDANG & TIDAK & N1 & M0 & II \\
\hline EC6 & SEDANG & TIDAK & N2 & M0 & III \\
\hline EC7 & KECIL & TIDAK & N2 & M0 & III \\
\hline EC8 & BESAR & YA & N3 & M0 & III \\
\hline EC9 & SEDANG & YA & N3 & M0 & III \\
\hline EC10 & BESAR & YA & N1 & M0 & III \\
\hline EC11 & BESAR & TIDAK & N1 & M0 & III \\
\hline EC12 & SEDANG & YA & N0 & M0 & III \\
\hline EC13 & BESAR & YA & N2 & M0 & III \\
\hline EC14 & BESAR & YA & N0 & M0 & III \\
\hline EC15 & SEDANG & YA & N2 & M0 & III \\
\hline EC16 & SEDANG & YA & N1 & M0 & III \\
\hline EC17 & SEDANG & TIDAK & N3 & M0 & III \\
\hline EC18 & BESAR & YA & N3 & M1 & IV \\
\hline EC19 & SEDANG & YA & N2 & M1 & IV \\
\hline EC20 & BESAR & YA & N2 & M1 & IV \\
\hline
\end{tabular}

Setelah dilakukan Equivalence Class, maka diperoleh 20 kelas yang berbeda dari 135 data. Sebelum pengolahan selanjutnya, nama - nama pada atribut akan ditransformasikan menggunakan huruf dan nilai dari setiap atribut akan ditransformasikan dengan angka untuk mempermudah dalam proses pengolahan data. Berikut adalah transformasi dari tiap atribut. 
Tabel 4 : Transformasi Data Atribut

\begin{tabular}{|l|l|}
\hline Ukuran Tumor = A & Kelenjar Getah Bening = C \\
$>\quad$ Kecil $=1$ & $>\mathrm{N} 0=0$ \\
$>\quad$ Sedang $=2$ & $>\mathrm{N} 1=1$ \\
$>\quad$ Besar $=3$ & $>\mathrm{N} 2=2$ \\
Perluasan Tumor = B & N3 $=3$ \\
$>\quad$ Ya $=1$ & Penyebaran Jauh = D \\
$>\quad$ Tidak $=2$ & $>\mathrm{M} 0=0$ \\
Stadium $=\mathrm{E}$ & $>\mathrm{M} 1=1$ \\
\hline
\end{tabular}

Sehingga tabel Equivalence Class akan lebih sederhana seperti berikut ini.

Tabel 4 : Hasil transformasi data atribut

\begin{tabular}{|c|c|c|c|c|c|}
\hline EC & A & B & C & D & E \\
\hline EC1 & KECIL & TIDAK & N0 & M0 & I \\
\hline EC2 & KECIL & TIDAK & N1 & M0 & I \\
\hline EC3 & SEDANG & TIDAK & N0 & M0 & II \\
\hline EC4 & BESAR & TIDAK & N0 & M0 & II \\
\hline EC5 & SEDANG & TIDAK & N1 & M0 & II \\
\hline EC6 & SEDANG & TIDAK & N2 & M0 & III \\
\hline EC7 & KECIL & TIDAK & N2 & M0 & III \\
\hline EC8 & BESAR & YA & N3 & M0 & III \\
\hline EC9 & SEDANG & YA & N3 & M0 & III \\
\hline EC10 & BESAR & YA & N1 & M0 & III \\
\hline EC11 & BESAR & TIDAK & N1 & M0 & III \\
\hline EC12 & SEDANG & YA & N0 & M0 & III \\
\hline EC13 & BESAR & YA & N2 & M0 & III \\
\hline EC14 & BESAR & YA & N0 & M0 & III \\
\hline EC15 & SEDANG & YA & N2 & M0 & III \\
\hline EC16 & SEDANG & YA & N1 & M0 & III \\
\hline EC17 & SEDANG & TIDAK & N3 & M0 & III \\
\hline EC18 & BESAR & YA & N3 & M1 & IV \\
\hline EC19 & SEDANG & YA & N2 & M1 & IV \\
\hline EC20 & BESAR & YA & N2 & M1 & IV \\
\hline
\end{tabular}




\subsubsection{Matrix Discernibility}

Discernibility Matrix adalah suatu matriks yang berisikan perbandingan antar data yang berbeda nilai atribut kondisi dengan cara membandingkan setiap Class. Nilai atribut kondisi yang berbeda akan dituliskan pada tabel Discernibility Matrix, sedangkan jika semua nilai atribut kondisi sama maka tuliskan dengan tanda "X". Missal pada Tabel 4 EC1 dan EC2 akan dicari nilai atribut yang berbeda yaitu atribut $\mathrm{C}$, sehingga pada baris pertama dan kolom kedua pada Discernibility Matrix (Lihat Tabel 4) diisi dengan "C" sedangkan jika seluruh nilai atributnya sama maka akan diisi " $X$ " seperti pada baris 1 kolom 1 . Berikut adalah tabel dari Discernibility Matrix 10 kelas.

Tabel 5 : Discernibility Matrix.

\begin{tabular}{|c|c|c|c|c|c|c|c|c|c|c|}
\hline $\mathrm{EC}$ & 1 & 2 & 3 & 4 & 5 & 6 & 7 & 8 & 9 & 10 \\
\hline 1 & $\mathrm{X}$ & $\mathrm{C}$ & $\mathrm{A}$ & $\mathrm{A}$ & $\mathrm{AC}$ & $\mathrm{AC}$ & $\mathrm{C}$ & $\mathrm{ABC}$ & $\mathrm{ABC}$ & $\mathrm{ABC}$ \\
\hline 2 & $\mathrm{C}$ & $\mathrm{X}$ & $\mathrm{AC}$ & $\mathrm{AC}$ & $\mathrm{A}$ & $\mathrm{AC}$ & $\mathrm{C}$ & $\mathrm{ABC}$ & $\mathrm{ABC}$ & $\mathrm{AB}$ \\
\hline 3 & $\mathrm{~A}$ & $\mathrm{AC}$ & $\mathrm{X}$ & $\mathrm{A}$ & $\mathrm{A}$ & $\mathrm{C}$ & $\mathrm{AC}$ & $\mathrm{ABC}$ & $\mathrm{BC}$ & $\mathrm{ABC}$ \\
\hline 4 & $\mathrm{~A}$ & $\mathrm{AC}$ & $\mathrm{A}$ & $\mathrm{X}$ & $\mathrm{AC}$ & $\mathrm{AC}$ & $\mathrm{AC}$ & $\mathrm{ABC}$ & $\mathrm{ABC}$ & $\mathrm{BC}$ \\
\hline 5 & $\mathrm{AC}$ & $\mathrm{A}$ & $\mathrm{C}$ & $\mathrm{AC}$ & $\mathrm{X}$ & $\mathrm{C}$ & $\mathrm{AC}$ & $\mathrm{ABC}$ & $\mathrm{BC}$ & $\mathrm{AB}$ \\
\hline 6 & $\mathrm{AC}$ & $\mathrm{AC}$ & $\mathrm{C}$ & $\mathrm{AC}$ & $\mathrm{C}$ & $\mathrm{X}$ & $\mathrm{A}$ & $\mathrm{ABC}$ & $\mathrm{BC}$ & $\mathrm{ABC}$ \\
\hline 7 & $\mathrm{C}$ & $\mathrm{C}$ & $\mathrm{AC}$ & $\mathrm{AC}$ & $\mathrm{AC}$ & $\mathrm{A}$ & $\mathrm{X}$ & $\mathrm{ABC}$ & $\mathrm{ABC}$ & $\mathrm{ABC}$ \\
\hline 8 & $\mathrm{ABC}$ & $\mathrm{ABC}$ & $\mathrm{ABC}$ & $\mathrm{ABC}$ & $\mathrm{ABC}$ & $\mathrm{ABC}$ & $\mathrm{ABC}$ & $\mathrm{X}$ & $\mathrm{A}$ & $\mathrm{C}$ \\
\hline 9 & $\mathrm{ABC}$ & $\mathrm{ABC}$ & $\mathrm{BC}$ & $\mathrm{ABC}$ & $\mathrm{BC}$ & $\mathrm{BC}$ & $\mathrm{ABC}$ & $\mathrm{A}$ & $\mathrm{X}$ & $\mathrm{AC}$ \\
\hline 10 & $\mathrm{ABC}$ & $\mathrm{AB}$ & $\mathrm{ABC}$ & $\mathrm{BC}$ & $\mathrm{AB}$ & $\mathrm{ABC}$ & $\mathrm{ABC}$ & $\mathrm{C}$ & $\mathrm{AC}$ & $\mathrm{X}$ \\
\hline
\end{tabular}

\subsubsection{Matrix Discernibility Modulo D}

Discernibility Matrix modulo $D$ adalah matriks pengembangan dari Discernibility Matrix yaitu bandingkan setiap class berdasarkan atribut keputusan, jika atribut keputusannya sama maka tuliskan tanda " $X$ ", jika atribut keputusannya berbeda maka tuliskan perbedaan atributnya berdasarkan tabel Discernibility Matrix. Misal EC1 dan EC2 (lihat Tabel 5) memiliki nilai keputusan yang sama, maka pada baris 1 dan kolom 2 begitupun dengan baris 2 kolom 1 (Lihat Tabel 6) di isi "X" Berikut adalah tabel dari Discernibility Matrix modulo D.

Tabel 6 : Discernibility Matrix Modulo D.

\begin{tabular}{|c|c|c|c|c|c|c|c|c|c|c|}
\hline $\mathrm{EC}$ & 1 & 2 & 3 & 4 & 5 & 6 & 7 & 8 & 9 & 10 \\
\hline 1 & $\mathrm{X}$ & $\mathrm{X}$ & $\mathrm{A}$ & $\mathrm{A}$ & $\mathrm{AC}$ & $\mathrm{AC}$ & $\mathrm{C}$ & $\mathrm{ABC}$ & $\mathrm{ABC}$ & $\mathrm{ABC}$ \\
\hline 2 & $\mathrm{X}$ & $\mathrm{X}$ & $\mathrm{AC}$ & $\mathrm{AC}$ & $\mathrm{A}$ & $\mathrm{AC}$ & $\mathrm{C}$ & $\mathrm{ABC}$ & $\mathrm{ABC}$ & $\mathrm{AB}$ \\
\hline 3 & $\mathrm{~A}$ & $\mathrm{AC}$ & $\mathrm{X}$ & $\mathrm{X}$ & $\mathrm{X}$ & $\mathrm{C}$ & $\mathrm{AC}$ & $\mathrm{ABC}$ & $\mathrm{BC}$ & $\mathrm{ABC}$ \\
\hline 4 & $\mathrm{~A}$ & $\mathrm{AC}$ & $\mathrm{X}$ & $\mathrm{X}$ & $\mathrm{X}$ & $\mathrm{AC}$ & $\mathrm{AC}$ & $\mathrm{ABC}$ & $\mathrm{ABC}$ & $\mathrm{BC}$ \\
\hline 5 & $\mathrm{AC}$ & $\mathrm{A}$ & $\mathrm{X}$ & $\mathrm{X}$ & $\mathrm{X}$ & $\mathrm{C}$ & $\mathrm{AC}$ & $\mathrm{ABC}$ & $\mathrm{BC}$ & $\mathrm{AB}$ \\
\hline 6 & $\mathrm{AC}$ & $\mathrm{AC}$ & $\mathrm{C}$ & $\mathrm{AC}$ & $\mathrm{C}$ & $\mathrm{X}$ & $\mathrm{X}$ & $\mathrm{X}$ & $\mathrm{X}$ & $\mathrm{X}$ \\
\hline
\end{tabular}




\begin{tabular}{|c|c|c|c|c|c|c|c|c|c|c|}
\hline 7 & $\mathrm{C}$ & $\mathrm{C}$ & $\mathrm{AC}$ & $\mathrm{AC}$ & $\mathrm{AC}$ & $\mathrm{X}$ & $\mathrm{X}$ & $\mathrm{X}$ & $\mathrm{X}$ & $\mathrm{X}$ \\
\hline 8 & $\mathrm{ABC}$ & $\mathrm{ABC}$ & $\mathrm{ABC}$ & $\mathrm{ABC}$ & $\mathrm{ABC}$ & $\mathrm{X}$ & $\mathrm{X}$ & $\mathrm{X}$ & $\mathrm{X}$ & $\mathrm{X}$ \\
\hline 9 & $\mathrm{ABC}$ & $\mathrm{ABC}$ & $\mathrm{BC}$ & $\mathrm{ABC}$ & $\mathrm{BC}$ & $\mathrm{X}$ & $\mathrm{X}$ & $\mathrm{X}$ & $\mathrm{X}$ & $\mathrm{X}$ \\
\hline 10 & $\mathrm{ABC}$ & $\mathrm{AB}$ & $\mathrm{ABC}$ & $\mathrm{BC}$ & $\mathrm{AB}$ & $\mathrm{X}$ & $\mathrm{X}$ & $\mathrm{X}$ & $\mathrm{X}$ & $\mathrm{X}$ \\
\hline
\end{tabular}

\subsubsection{Reduct}

Setelah dilakukan proses penyeleksian atribut reduct, sehingga diperoleh atribut reduct berjumlah 35 dari 20 EC. Atribut reduct itulah yang akan dijadikan sebagai rule dalam penentuan keputusan.

Tabel 7 : Hasil seleksi atribut reduct

\begin{tabular}{|c|c|c|c|c|c|c|c|}
\hline EC & $A$ & $B$ & C & D & stad & reduct & possibility \\
\hline 1 & KECIL & TIDAK & No & MO & I & $A C$ & 1 \\
\hline 2 & KECIL & TIDAK & N1 & MO & I & $A C$ & 1 \\
\hline 3 & SEDANG & TIDAK & NO & MO & II & $A B C$ & 1 \\
\hline 4 & BESAR & TIDAK & NO & MO & II & $A B C$ & 1 \\
\hline 5 & SEDANG & TIDAK & N1 & MO & II & $A B C$ & 1 \\
\hline \multirow{2}{*}{6} & \multirow{2}{*}{ SEDANG } & \multirow{2}{*}{ TIDAK } & \multirow{2}{*}{ N2 } & \multirow{2}{*}{ MO } & \multirow{2}{*}{ III } & $B C$ & 1 \\
\hline & & & & & & CD & 1 \\
\hline \multirow{3}{*}{7} & \multirow{3}{*}{ KECIL } & \multirow{3}{*}{ TIDAK } & \multirow{3}{*}{$\mathrm{N} 2$} & \multirow{3}{*}{ MO } & \multirow{3}{*}{ III } & $A C$ & 1 \\
\hline & & & & & & $\mathrm{BC}$ & 1 \\
\hline & & & & & & $C D$ & 1 \\
\hline \multirow{2}{*}{8} & \multirow{2}{*}{ BESAR } & \multirow{2}{*}{ YA } & \multirow{2}{*}{ N3 } & \multirow{2}{*}{ MO } & \multirow{2}{*}{ III } & BD & 1 \\
\hline & & & & & & CD & 1 \\
\hline \multirow{3}{*}{9} & \multirow{3}{*}{ SEDANG } & \multirow{3}{*}{ YA } & \multirow{3}{*}{ N3 } & \multirow{3}{*}{ MO } & \multirow{3}{*}{ III } & $A C$ & 1 \\
\hline & & & & & & CD & 1 \\
\hline & & & & & & BD & 1 \\
\hline \multirow{3}{*}{10} & \multirow{3}{*}{ BESAR } & \multirow{3}{*}{ YA } & \multirow{3}{*}{ N1 } & \multirow{3}{*}{ MO } & \multirow{3}{*}{ III } & $B C$ & 1 \\
\hline & & & & & & BD & 1 \\
\hline & & & & & & $A C$ & 1 \\
\hline 11 & BESAR & TIDAK & N1 & MO & III & $A C$ & 1 \\
\hline \multirow{2}{*}{12} & \multirow{2}{*}{ SEDANG } & YA & No & $M 0$ & 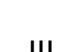 & $\mathrm{BC}$ & 1 \\
\hline & & הוד & 10 & TVir & III & BD & 1 \\
\hline & & VA & N & $M 0$ & 11 & BD & 1 \\
\hline 10 & DESAR & $T A$ & IN2 & IVIO & III & $C D$ & 1 \\
\hline 11 & RECAP & VA & $N \cap$ & $M 0$ & 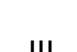 & $\mathrm{BC}$ & 1 \\
\hline 14 & DESAR & $1 A$ & INO & TViv & III & BD & 1 \\
\hline 15 & SEDANG & YA & $\mathrm{N} 2$ & MO & III & BD & 1 \\
\hline
\end{tabular}




\begin{tabular}{|c|c|c|c|c|c|c|c|}
\hline & & & & & & CD & 1 \\
\hline \multirow{2}{*}{16} & \multirow{2}{*}{ SEDANG } & \multirow{2}{*}{ YA } & \multirow{2}{*}{$\mathrm{N} 1$} & \multirow{2}{*}{ MO } & \multirow{2}{*}{ III } & $B C$ & 1 \\
\hline & & & & & & BD & 1 \\
\hline \multirow{3}{*}{17} & \multirow{3}{*}{ SEDANG } & \multirow{3}{*}{ TIDAK } & \multirow{3}{*}{ N3 } & \multirow{3}{*}{ MO } & \multirow{3}{*}{ III } & $B C$ & 1 \\
\hline & & & & & & $A C$ & 1 \\
\hline & & & & & & CD & 1 \\
\hline 18 & BESAR & YA & N3 & M1 & IV & $D$ & 1 \\
\hline 19 & SEDANG & YA & $\mathrm{N} 2$ & M1 & IV & $D$ & 1 \\
\hline 20 & BESAR & YA & N2 & M1 & IV & D & 1 \\
\hline
\end{tabular}

\subsubsection{Aturan Keputusan}

Proses selanjutnya yaitu mendapatkan rule - rule dalam database melalui ekstraksi rule dari sistem keputusan. Hasil keputusan tersebut didasarkan pada proses reduct. Berikut adalah aturan keputusan berdasarkan tabel hasil seleksi atribut reduct.

Tabel 8 : Aturan keputusan

\begin{tabular}{|l|l|c|c|}
\hline No & \multicolumn{1}{|c|}{ Rules } & Banyak & possibility \\
\hline 1 & Jika A = KECIL dan C = N0 maka STADIUM = I & 1 & 1 \\
\hline 2 & Jika A = KECIL dan C = N1 maka STADIUM = I & 1 & 1 \\
\hline 3 & $\begin{array}{l}\text { Jika A = SEDANG dan B = TIDAK dan C = N0 maka } \\
\text { STADIUM = II }\end{array}$ & 1 & 1 \\
\hline 4 & $\begin{array}{l}\text { Jika A = BESAR dan B = TIDAK dan C = N0 maka } \\
\text { STADIUM = II }\end{array}$ & 1 & 1 \\
\hline 5 & $\begin{array}{l}\text { Jika A = SEDANG dan B = TIDAK dan C = N1 maka } \\
\text { STADIUM = II }\end{array}$ & 1 & 1 \\
\hline 6 & Jika B = TIDAK dan C = N2 maka STADIUM = III & 2 & 1 \\
\hline 7 & Jika C = N2 dan D = M0 maka STADIUM = III & 4 & 1 \\
\hline 8 & Jika A = KECIL dan C = N2 maka STADIUM = III & 1 & 1 \\
\hline 9 & Jika C = N3 dan D = M0 maka STADIUM = III & 3 & 1 \\
\hline 10 & Jika B = YA dan D = M0 maka STADIUM = III & 8 & 1 \\
\hline 11 & Jika A = SEDANG dan C = N3 maka STADIUM = III & 2 & 1 \\
\hline 12 & Jika B = YA dan C = N1 maka STADIUM = III & 2 & 1 \\
\hline 13 & Jika A = BESAR dan C = N1 maka STADIUM = III & 2 & 1 \\
\hline 14 & Jika B = YA dan C = N0 maka STADIUM = III & 2 & 1 \\
\hline 15 & Jika B = TIDAK dan C = N3 maka STADIUM = III & 1 & 1 \\
\hline 16 & Jika D = M1 maka STADIUM =IV & 3 & 1 \\
\hline & & & \\
\hline
\end{tabular}


Melihat Tabel aturan keputusan tersebut dapat diketahui bahwa terdapat 16 rule yang berbeda dari 35 rule, yaitu Stadium I terdapat 2 rule, Stadium II terdapat 3 rule, Stadium III terdapat 27 rule dan Stadium IV terdapat 3 rule.

\subsection{Implementasi Metode Rough Set Menggunakan Software Rosetta}

Rosetta merupakan suatu software untuk pengolahan data yang menggunakan metode rough set. Dari data yang diperoleh kemudian diolah pada software rosetta, maka diperoleh aturan keputusannya yaitu 35 rule yang berdasarkan atribut reduct dengan 16 rule yang berbeda dari 35 rule tersebut. Berikut ini adalah Gambar dari rules yang diperoleh dari software rosetta.

\begin{tabular}{|c|c|c|c|c|c|}
\hline \multicolumn{6}{|c|}{ Rosetta - [Rules] } \\
\hline \multicolumn{6}{|c|}{ III File Edit View Window Help } \\
\hline \multicolumn{6}{|c|}{ 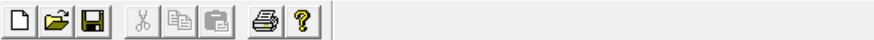 } \\
\hline & & Rule & LHS Support & RHS Support & RHS Accuracy \\
\hline 1 & & A(KECIL) AND C(NO) $\Rightarrow>$ STADIUM(I) & 1 & 1 & 1.0 \\
\hline 2 & & A(KECIL) AND C(N1) => STADIUM(I) & 1 & 1 & 1.0 \\
\hline 3 & & A(SEDANG) AND B(TIDAK) AND C(N0) $\Rightarrow$ STADIUM (II) & 1 & 1 & 1.0 \\
\hline 4 & & A(BESAR) AND B(TIDAK) AND C(NO) $\Rightarrow>$ STADIUM(II) & 1 & 1 & 1.0 \\
\hline 5 & & A(SEDANG) AND B(TIDAK) AND C(N1) $\Rightarrow>$ STADIUM(II) & 1 & 1 & 1.0 \\
\hline 6 & & C(N2) AND D $(M 0) \Rightarrow$ STADIUM(III) & 4 & 4 & 1.0 \\
\hline 7 & & B(TIDAK) AND C(N2) $\Rightarrow$ STADIUM(III) & 2 & 2 & 1.0 \\
\hline 8 & & A(KECIL) AND C(N2) $\Rightarrow$ S STADIUM(III) & 1 & 1 & 1.0 \\
\hline 9 & & C(N3) AND D(MO) $\Rightarrow$ STADIUM(III) & 3 & 3 & 1.0 \\
\hline 10 & & B(YA) AND D(MO) $\Rightarrow>$ STADIUM(III) & 8 & 8 & 1.0 \\
\hline 11 & & A(SEDANG) AND C(N3) $\Rightarrow>$ STADIUM(III) & 2 & 2 & 1.0 \\
\hline 12 & & A(BESAR) AND C(N1) => STADIUM(III) & 2 & 2 & 1.0 \\
\hline 13 & & 3(YA) AND C(N1) $\Rightarrow$ STADIUM(III) & 2 & 2 & 1.0 \\
\hline 14 & & B(YA) AND C(NO) $\Rightarrow$ STADIUM(III) & 2 & 2 & 1.0 \\
\hline 15 & & 3(TIDAK) AND C(N3) $\Rightarrow>$ STADIUM(III) & 1 & 1 & 1.0 \\
\hline 16 & & (M1) $=>$ STADIUM $(\mathrm{N})$ & 3 & 3 & 1.0 \\
\hline
\end{tabular}

Gambar 1 : Aturan Keputusan Rosetta

Dari proses pengolahan data menggunakan software rosetta diperoleh hasil yang sama dengan proses secara manual yaitu terdapat 16 rule yang berbeda dari 35 rule. Dari 35 rule yang diperoleh terdapat 2 rule Stadium I, 3 rule Stadium II, 27 rule Stadium III dan Stadium IV terdapat 3 rule.

\subsection{Rancang Bangun Aplikasi Sistem Pendukung Pengambilan Keputusan}

Perancangan sebuah aplikasi yang berfungsi sebagai sistem pendukung keputusan untuk mendignosa stadium kanker yang menggunakan metode rough set disertai pula dengan penyimpanan data yang telah di input pada aplikasi tersebut. Adapun aplikasi sistem pendukung keputusan pada penelitian ini menggunakan GUI NETBEAN dapat dilihat pada Gambar 2. 


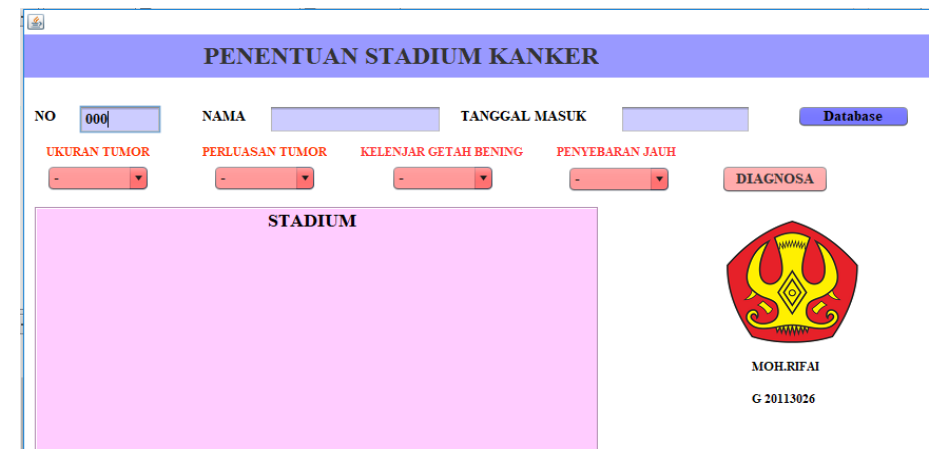

Gambar 2 : Tampilan utama Aplikasi

\subsection{Database Pasien Kanker Payudara}

Pada penelitian ini penulis membuat sebuah penyimpana data - data yang telah di input sebagai database pasien. Untuk melihat daftar database klik tombol "Database" sehingga akan muncul tampilan database seperti pada Gambar 3.

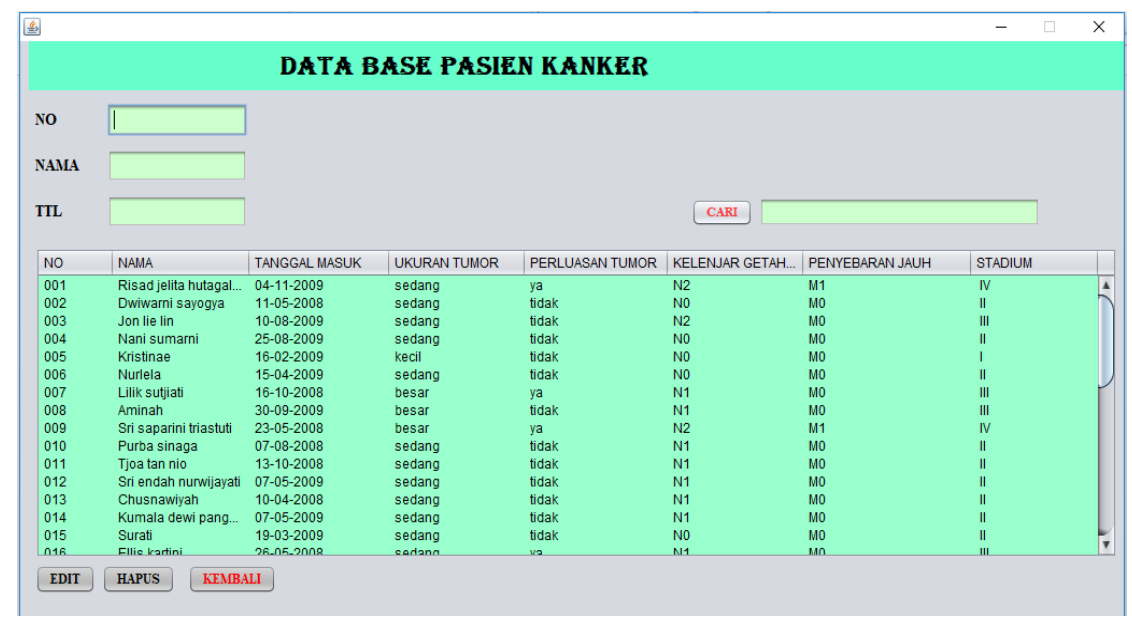

Gambar 3 : Tampilan Database

\subsection{Pengujian Tinggkat Akurasi Sistem}

Pengujian sistem merupakan serangkaian tahapan untuk menguji ketangguhan dari sistem yang telah dibangun dengan tujuan untuk menemukan kesalahan - kesalahan atau kekurangan - kekurangan pada sistem. Proses pengujian dilakukan untuk menguji model yang diperoleh dari proses sebelumnya yaitu proses training. Data yang digunakan untuk melakukan pengujian adalah sebanyak 135 data. Prosedur pengujian dilakukan dengan membandingkan hasil dari sistem pengambilan keputusan dengan hasil diagnosa dari pihak dokter. Berikut adalah tabel perbandingannya, penulis menampilkan 10 data . 
Tabel 9 : Hasil Perbandingan

\begin{tabular}{|c|c|c|c|c|c|c|c|}
\hline No & $\begin{array}{c}\text { Ukuran } \\
\text { Tumor }\end{array}$ & $\begin{array}{c}\text { Perluasan } \\
\text { Tumor }\end{array}$ & KGB & $\begin{array}{c}\text { Penyebaran } \\
\text { Jauh }\end{array}$ & Stadium & $\begin{array}{c}\text { Hasil } \\
\text { Sistem }\end{array}$ & Ket \\
\hline 1 & SEDANG & YA & N2 & M1 & IV & IV & Sama \\
\hline 2 & SEDANG & TIDAK & N0 & M0 & II & II & Sama \\
\hline 3 & SEDANG & TIDAK & N2 & M0 & III & III & Sama \\
\hline 4 & SEDANG & TIDAK & N0 & M0 & II & II & Sama \\
\hline 5 & KECIL & TIDAK & N0 & M0 & I & I & Sama \\
\hline 6 & SEDANG & TIDAK & N0 & M0 & II & II & Sama \\
\hline 7 & BESAR & YA & N1 & M0 & III & III & Sama \\
\hline 8 & BESAR & TIDAK & N1 & M0 & III & III & Sama \\
\hline 9 & BESAR & YA & N2 & M1 & IV & IV & Sama \\
\hline 10 & SEDANG & TIDAK & N1 & M0 & II & II & Sama \\
\hline
\end{tabular}

Melihat Tabel hasil perbandingan diatas, dapat diketahui akurasi dari sistem tersebut dengan rumus sebagai berikut:

Akurasi $=\frac{\text { data yang sama }}{\text { banyak data } u j i} \times 100 \%$

Dari pengujian 135 data, diperoleh data yang sama sebanyak 135. Dengan rumus tersebut dapat diperoleh akurasinya yaitu :

$$
=\frac{135}{135} \times 100 \%=100 \%
$$

Sehingga, dapat disimpulkan sistem yang telah dibangun tersebut memiliki akurasi sebesar $100 \%$.

\section{KESIMPULAN}

Berdasarkan hasil penelitian yang telah dilakukan dapat disimpulkan.

1. Hasil klasifikasi pasien kanker payudara diperoleh aturan keputusan (decision rules) sebanyak 16 rule yang berbeda dari 35 rule yang telah diperoleh. Rule tersebut akan dijadikan sebagai acuan untuk mengambil keputusan berikutnya.

2. Akurasi yang di peroleh dari sistem pengambilan keputusan adalah $100 \%$ dengan menguji 135 data. 


\section{DAFTAR PUSTAKA}

[1]. Beny I, Analisis Kinerja Metode Rough Set Dan Algoritma Apriori Dalam Identifikasi Pola Penyakit Demam Tifoid, Tesis, 2016, Fakultas Ilmu Komputer dan Teknologi Informasi, Universitas Sumatera utara, Medan.

[2]. M. Ardiansyah \& Zulfi A, Implementasi Metode Rough Set Untuk Menganalisa Laba/Rugi Pada Suatu Perusahaan Distributor (Studi Kasus : Usaha Kita Ps Payakumbuh), 2015, Teknologi dan Sistem Informasi, 2, 3.

[3]. Nila L, Wiwik A, Ahmad M, Implementasi Algoritma Rough Set untuk Deteksi dan Penanganan Dini Penyakit Sapi, Informatika AMIK-LB, 2011, 2, 1.

[4]. Ruri A.H, A. Rizal, B. Hidayat, Penentuan Stadium (Staging) Kanker Payudara Berdasarkan Faktor Tnm (Tumor Size, Node, Metastasis) Dengan Menggunakan Metode Region Growing. Telkom University, 2010, 1,1.

[5]. Suhardi, A. Setiawan \& I. Hidayah, Seleksi Rule Menggunakan Rough Set Theory Untuk Diagnosis Penyakit Tuberkulosis. Teknologi Industri dan Informasi, 2015, 9,1. 